\title{
Sanksi bagi Perusahaan Pers yang Melakukan Tindak Sub Judice Rule dalam Perspektif Hukum Pidana Islam dan Pasal 18 Ayat (2) Undang- Undang nomor 40 tahun 1999 tentang Pers
}

\author{
Achmad \\ STAI Syaicona Moh Cholil Bangkalan Madura \\ Email: rosulahmad9@gmail.com
}

\begin{abstract}
Abstrak: This research is the result of library research conducted on the basis of problems that have often occurred recently, where the press has started to interfere too far in cases currently being handled by the judiciary, or rather the press has committed acts of Sub Judice Rule. This study aims to answer the questions, namely 1 . What is the criminal sanction for the sub-judice rule according to Article 18 Paragraph (2) of Law Number 40 Year 1999 concerning the Press? 2. What is the criminal sanction for the sub-judice rule according to Islamic Criminal Law? The author, with the above problems, then studies and researches to solve these problems with library research using the descriptive method used to describe the concept of the subjudice rule criminal act in Article 18 paragraph (2) of Law Number 40 of 1999 about the press. Furthermore, it is analyzed with a Deductive mindset that originates from basic principles and is combined with research using the perspective of Islamic Criminal Law. It is analyzed for specific conclusions regarding the general description of the subjudice rule by the press according to Law No. 40 of 1999 concerning the press then draw conclusions that are specific to Islamic criminal law. The conclusion from the results of this study can be seen that the sanctions for criminal acts of the sub-judice rule contained in Article 18 paragraph (2) of Law Number 40 of 1999 concerning the press, namely, shall be punished with a maximum fine of Rp. 500,000,000.00 (Five hundred million rupiah). Sub-judice rule is a criminal act of insulting the court by means of publication, which in this case is classified as a takzir, because neither the type nor the sanctions are determined by the syarak, so that the determination of the penalty is fully left to Ulil Amri.
\end{abstract}

Key words: contempt of court. Islamic criminal law, sub judice rule 


\section{Pendahuluan}

Sebagai negara hukum Indonesia merupakan Negara yang berlandaskan Pancasila dan Undang-Undang Dasar Negara Republik Indonesia Tahun 1945 telah mengakui bahwa kemerdekaan pers merupakan salah satu bentuk dari kedaulatan rakyat dan merupakan bagian penting dari terselenggaranya atau terciptanya kehidupan bermasyarakat, berbangsa dan bernegara yang demokratis.

Pers merupakan bagian yang sangat penting dan berpengaruh dalam penyebaran informasi pembentukan opini publik. Jika dilihat dari perkembangannya ketika Indonesia masih dalam masa penjajahan, surat kabar juga memiliki andil penting dalam proses pencapaian kemerdekaan, pada saat itu kaum muda menggunakan surat kabar sebagai media untuk menumbuhkan semangat pergerakan nasional.

Sementara pada masa orde baru dianggap sebagai masa terburuk bagi kehidupan pers nasional, karena pada masa itu pers tidak dapat dengan bebas menjalankan fungsinya, segala sesuatunya diatur oleh pemerintah mulai dari jumlah perusahaan pers hingga sajian pemberitaan yang harus mengikuti aturan yang telah ditetapkan. Sejalan dengan runtuhnya orde baru, masa reformasi merupakan kebangkitan bagi kemerdekaan pers, kemudian lahirlah wadah hukum yang menjembatani kebebasan berpikir, dan beraspirasi melalui pers dan media massa yang dituangkan dalam Undang-Undang Nomor 40 Tahun 1999 Tentang Pers.

Terbitnya Undang-Undang Nomor 40 Tahun 1999 Tentang Pers yang kemudian menguatkan kedudukan pers, dan menjadi payung hukum atas kemerdekaan pers yang di dalamnya diatur mengenai asas, fungsi, hak, kewajiban dan peranan pers nasional, juga sanksi bagi pihak yang melampaui batasan yang 
telah ada, seperti yang terkandung dalam Pasal 18 Ayat (2) Undang-Undang Nomor 40 Tahun 1999 Tentang Pers yang berbunyi; Perusahaan pers yang melanggar ketentuan Pasal 5 Ayat (1) dan Ayat (2) ${ }^{1}$, serta Pasal $13^{2}$ dipidana dengan pidana denda paling banyak Rp 500.000.000,00 (Lima ratus juta rupiah)". ${ }^{3}$

Kebebasan yang kini dimiliki pers membuat para pekerja pers lebih mudah menjalankan fungsi dan perannya secara optimal. Kebebasan pers yang bertanggung jawab merupakan wujud dari demokrasi dan merupakan salah satu syarat bagi negara dalam memperjuangkan kemajuan bangsa dan negara. Namun kebebasan pers kadangkala lupa batasan hingga sampai kebablasan, karena berita atau tayangan yang disebarkan melalui media cetak/elektronik telah menyimpang dari koridor yang ditetapkan oleh hukum, budaya dan agama. Seperti halnya ketika pemberitaan pers digunakan sebagai alat untuk memfitnah atau menghina seseorang, atau bahkan lembaga peradilan, dengan memberi komentar negatif terhadap suatu kasus yang tengah ditangani. Tindakan ini kemudian diistilahkan dengan sebutan sub judice rule.

Sedangkan dalam hukum pidana Islam tidak dijelaskan secara tegas baik dalam Al-quran atau hadits tentang tindakan sub judice rule ini, mulai dari aturan teknis sampai jenis hukumannya. Namun secara tersirat banyak Ayat-Ayat yang mengandung tentang pentingnya menjaga nilai-nilai keadilan,

1. Ayat (1) Pers nasional berkewajiban memberitakan peristiwa dan opini dengan menghormati norma-norma agama dan rasa kesusilaan masyarakat serta asas praduga tak bersalah. Ayat(2) Pers wajib melayani Hak Jawab

2. Perusahaan iklan dilarang memuat iklan: (a) yang berakibat merendahkan martabat suatu agama dan atau mengganggu kerukunan hidup antarumat beragama, serta bertentangan dengan rasa kesusilaan masyarakat. (b) minuman keras, narkotika, psikotropika, dan zat adiktif lainnya sesuai dengan ketentuan peraturan per Undang-Undangan yang berlaku. (c) peragaan wujud rokok dan atau penggunaan rokok

3.Lihat Undang-Undang Nomor 40 Tahun 1999 Tentang Pers 
seperti makna yang terkandung dalam surat An-Nisa Ayat 135 yang berbunyi:

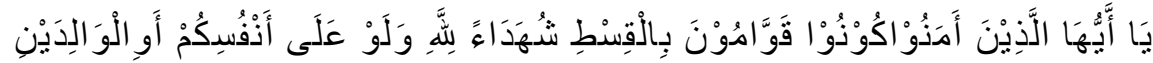

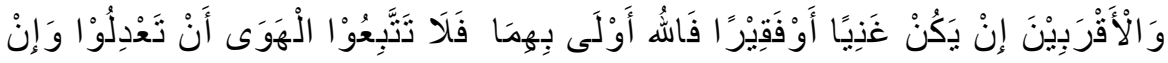

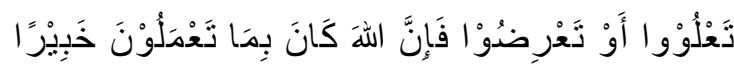

"Wahai orang-orang yang beriman, jadilah kamu orang yang benar benar penegak keadilan, menjadi saksi karna Allah biarpun terhadap dirimu sendiri orang tua atau kerabatmu. Jika ia kaya atau miskin, maka Allah lebih tahu kemaslahatannya. Maka janganlah kamu mengikuti hawa nafsu karna ingin menyimpang dari kebenaran. Dan jika kamu memutar balikkan (kata-kata) atau enggan menjadi saksi, maka sesungguhnya Allah adalah Maha Mengetahui segala apa yang kamu kerjakan". 4

Terdapat beberapa poin makna yang terkandung pada Ayat di atas. Pertama anjuran untuk menjadi penegak keadilan, yang bisa juga diartikan turut andil dan mendukung tegaknya keadilan. Kedua larangan untuk tidak mengikuti hawa nafsu, memutar balikan kata dalam memberikan persaksian yang tidak sesuai kenyataan atau bahkan melalui pemberitaan yang dibuatbuat karna ingin mengalihkan kebenaran. Poin kedua ini merupakan kandungan makna yang secara tersirat bisa ditarik pada permasalahan yang akan dibahas kali ini, terutama dalam hal memutarbalikan kata dalam persaksian ataupun dalam pemberitaan pers, untuk mengalihkan kebenaran yang sesungguhnya, sehingga dapat mengganggu tegaknya keadilan dan kebenaran.

Dewasa ini sering kita jumpai suatu kejadian dimana pers seakan-akan bertindak sebagai badan peradilan, dengan analisa yang mereka lakukan sendiri, mencari bukti-bukti dan mengkaji sendiri, untuk kemudian berakhir dengan sebuah putusan dalam pemberitaan yang disebarluaskan, sehingga kasus tersebut 
terangkat kepermukaan lantas masyarakat menganggap bahwa hal itu benar adanya.

Seperti kasus tentang wawancara fiktif yang terjadi di Surabaya tempo dulu. Seorang wartawan menayangkan hasil wawancaranya dengan seorang istri Nurdin M Top. Namun pada akhirnya terungkap kalau ternyata wawancara itu tidak pernah terjadi. Istri Nurdin M Top pada saat itu sedang sakit tenggorokan sehingga untuk bicara saja dia kesulitan, apalagi sampai memberi penjelasan panjang lebar sebagaimana yang telah di beritakan oleh wartawan itu, wartawan tersebut akhirnya mengaku jika sebenarnya ia tidak pernah bertemu dengan istri orang yang disangka teroris tersebut dan tidak ada wawancara sama sekali. ${ }^{5}$ Campur tangan dan tekanan yang dilakukan pers dalam sebuah kasus di pengadilan merupakan pelanggaran berupa sub judice rule yaitu penggiringan opini dalam pemberitaan yang berpotensi secara nyata membahayakan kemandirian peradilan.

Dengan demikian maka perlu adanya kajian lebih mendalam menyangkut permasalahan ini, mengingat tidak adanya penjelasan secara tegas baik dalam Per Undang-Undangan ataupun Hukum Pidana Islam, mulai dari aturan teknis sampai jenis hukuman yang berkaitan dengan tindakan sub judice rule.

\section{Metode Penelitian}

Pendekatan masalah yang akan digunakan dalam penelitian ini adalah.

\section{Pendekatan Konseptual}

Pendekatan konseptual (conceptual approach), digunakan manakala peneliti tidak beranjak dari peraturan hukum yang ada. Peneliti merujuk prinsip-prinsip hukum yang ada. Prinsipprinsip ini dapat ditemukan dalam pandangan-pandangan sarjana ataupun doktrin-doktrin hukum. Meski tidak secara 
eksplisit, konsep hukum juga dapat ditemukan dalam UndangUndang. Hanya saja dalam mengidentifikasi prinsip tersebut peneliti terlebih dahulu memahami konsep tersebut melalui pandangan-pandangan dan doktrin yang ada.

Pendekatan konseptual ini digunakan untuk mengkaji dan menganalisis kerangka pikir atau kerangka konseptual maupun landasan teoritis sesuai dengan tujuan penelitian ini yakni mengkaji secara yuridik tentang tindakan sub judice rule dengan mengaitkannya dengan Pasal 18 Ayat (2) UndangUndang No 40 Tahun 1999 Tentang Pers, dan juga pandangan Islam terhadap tindakan sub judice rule.

\section{Pendekatan Per Undang-Undangan (Statute Approach)}

Suatu penelitian normatif tentu harus menggunakan pendekatan perundang-undangan, karena yang akan diteliti adalah berbagai aturan hukum yang menjadi fokus sekaligus tema sentral suatu penelitian. ${ }^{6}$ Pendekatan Undang-Undang (statute approach) dilakukan dengan menelaah semua UndangUndang dan regulasi yang bersangkut paut dengan isu hukum yang sedang ditangani. ${ }^{7}$

Hasil dari telaah tersebut merupakan suatu argumen untuk memecahkan isu yang dihadapi. $^{8}$ Dengan demikian memahami kandungan filosofis yang ada di belakang peraturan perundang-undangan itu dapat disimpulkan mengenai ada tidaknya benturan filosofis antara peraturan perundangundangan dengan isu yang dihadapi. Pendekatan perundangundangan digunakan dalam penelitian ini guna menganalisis konsep, teori dan data-data yang terkait dengan Tindakan sub judice rule. Maka peraturan yang digunakan yaitu UndangUndang Dasar 1945 yang memiliki otoritas tertinggi, Kitab

6. Johnny Ibrahim. Teori \& Metodologi Penetitian Hukum Normatif. Bayumedia Publishing, Malang: 2010, hlm. 302

7. Ibid., hlm. 93.

8. Ibid., hlm. 94. 
Undang-Undang Hukum Pidana, termasuk Undang-Undang No 40 Tahun 1999 Tentang Pers dan juga kajian fiqih yang berkaitan dengan pokok pembahasan yang disertai dalil AlQur'an dan Al-Hadist.

Teknik Pengumpulan data yang digunakan dalam penelitian ini adalah teknik pengumpulan data dokumentasi. Data dokumentasi merupakan metode pengumpulan data dengan mengkaji berbagai dokumen yang diperlukan dalam penelitian. Dokumen-dokumen yang berhubungan dengan pokok pembahasan menurut hukum Islam, yaitu peraturan per Undang-Undangan, risalah resmi, dan dokumen, buku-buku, jurnal yang berkaitan dengan tindakan sub judice rule yang didapat dari perpustakaan. Data dokumen lainnya adalah nashnash dalam Al-Qur'an dan Al-Hadist tentang tindak penghinaan, fitnah dan penyebaran berita bohong, yang berkesinambungan dengan prinsip-prinsip dasar (asas hukum), pandangan para ahli hukum (doktrin), hasil penelitian hukum, kamus hukum dan ensiklopedia hukum serta pendapat ulama yang tertuang dalam kitab-kitab fikih.

Teknik analisis penelitian hukum normatif, yang digunakan adalah deskriptif analisis yaitu uraian apa adanya terhadap suatu kondisi atau posisi dari hukum atau non-hukum. Dalam penelitian ini, analisis data dilakukan dengan cara:

1) Evaluatif, yaitu melakukan penilaian/mengevaluasi tepat atau tidak tepat, benar atau tidak benar, sah atau tidak sah terhadap suatu pandangan, proposisi, pernyataan rumusan norma, keputusan baik yang tertera dalam bahan hukum primer, sekunder maupun tersier.

2) Interpretatif, yaitu menggunakan jenis penafsiran menurut per Undang-Undangan.

3) Kontruksi, yaitu pembentukan kontruksi-kontruksi yuridis dengan melakukan analogi dan pembalikan proposisi. 
3. Pembahasan

A. Sanksi Tindak Pidana Sub Judice Rule Dalam Pasal 18 Ayat (2) Undang-Undang Nomor 40 Tahun 1999 Tentang Pers.

Sub judice rule adalah suatu aturan umum yang berisikan tentang larangan bagi publik untuk ikut mencampuri urusan peradilan yang bebas dan tidak memihak untuk suatu kasus yang sedang atau akan diperiksa di pengadilan. Sub judice rule adalah suatu tindakan berupa memberi komentar di media tentang kasus yang sedang menunggu putusan, memberi informasi atau publikasi yang sifatnya memihak. ${ }^{9}$ Sedangkan menurut Prof. Oemar Seno Adji adalah, suatu usaha berupa perbuatan atau sikap yang ditujukan ataupun pernyataan secara lisan apalagi secara tulisan, yang nantinya menjadi persoalan pers dan aspek hukumnya untuk dapat mempengaruhi suatu putusan yang akan dijatuhkan oleh hakim. ${ }^{10}$

Menurut Andi Hamzah, yang dimaksud dengan perbuatan menghina atau persangkaan buruk yang hal ini menjadi inti pokok dari sub judice rule, yaitu menyerang kehormatan dan nama baik badan peradilan. Kehormatan yang diserang hanya mengenai kehormatan tentang nama baik. $^{11}$

Meskipun pegertian dasar mengenai sub judice rule di Negara kita baru terdefinisikan secara nyata bersamaan dengan lahirnya Undang-Undang Nomor 14 Tahun 1985, akan tetapi pada hakekatnya dalam KUHP, terdapat

9. Andi Sofyan, Hukum Acara Pidana Suatu Pengantar. Prenada Media 2017 hlm 434

10. Oemar Seno Adji, Contempt of Court suatu pemikiran, Jakarta: Erlangga, 1986, hlm 28 .

11. Andi Hamzah, Delik-Delik Terhadap Penyelenggaraan Peradilan (Contempt Of Court) Jakarta: Sinar Grafika 1989, hlm 3 
beberapa pasal yang dapat digolongkan pada delik sub judice rule. Jika kita melihat pada adanya unsur penghinaan, sebagaimana yang terkadung dalam pengertian sub judice rule itu sendiri, maka meskipun Undang Undang Nomor 14 Tahun 1985 belum lahir, kita tetap dapat menghukuminya dengan pasal-pasal dalam KUHP. Hanya saja setelah Undang Undang Nomor 14 itu lahir, maka definisi dan kandungan dari tindak sub judice rule menjadi lebih jelas dan khusus. Beda halnya dengan pasal-pasal di dalam KUHP yang definisinya masih begitu umum dan hanya mencakup tentang pasal penghinaan secara umum saja, dan tidak ada penghususan tentang tindak penghinaan terhadap badan peradilan.

Berikut macam-macam penghinaan dalam KUHP beserta sanksinya, yaitu:

1. Menghina suatu penguasa atau badan umum dengan lisan atau tulisan (Pasal 207) diancam dengan pidana penjara paling lama satu tahun enam bulan atau pidana denda paling banyak empat ribu lima ratus rupiah.

2. Menyiarkan, mempertunjukkan atau menempelkan di muka umum suatu tulisan atau lukisan yang memuat penghinaan terhadap penguasa atau badan umum (Pasal 208) diancam dengan pidana penjara paling lama empat bulan atau pidana denda paling banyak empat ribu lima ratus rupiah.

3. Pencemaran lisan dan pencemaran dengan tulisan/gambar (pasal 310) diancam dengan pidana penjara paling lama Sembilan bulan dan denda paling banyak empat ribu lima ratus rupiah

4. Fitnah (pasal 311) diancam dengan pidana penjara paling lama empat tahun

5. Pengaduan fitnah (pasal 317) diancam dengan pidana penjara paling lama empat tahun 
6. Menimbulkan persangkaan palsu (pasal 318) diancam dengan pidana penjara paling lama empat tahun. ${ }^{12}$

Terdapat beberapa pasal dalam KUHP, seperti Pasal 207, Pasal 208, pasal 310, pasal 311, pasal 317, pasal 318 yang mana jika kita pahami, isinya memuat tentang suatu perbuatan yang pada saat ini dikenal dengan sebutan sub judice rule, yang pengertiannya diatur lebih sepesifik lagi dalam Undang-Undang Nomor 14 Tahun 1985. Semua pasal di atas hanya dapat dituntut apabila ada pengaduan dari orang yang menderita, dinista, dihina (delik aduan), atau pihak yang dirugikan, kecuali bila penghinaan itu dilakukan terhadap seorang pegawai negeri pada waktu menjalankan tugasnya yang sah, sebut saja ketua pengadilan, para hakim dan seluruh jajarannya yang tengah melaksaankan tugas. Jika kita tarik persoalan di atas pada bentuk penghinaan yang dilakukan dengan mengunakan peran media massa atau pers, maka larangan itu diatur secara implisit dan lebih tegas dalam Pasal 5 Ayat (1) Undang-Undang Nomor 40 Tahun 1999 Tentang Pers, yang isinya sebagai berikut:

"Pers nasional berkewajiban memberitakan peristiwa dan opini dengan menghormati norma-norma agama dan rasa kesusilaan masyarakat serta asas praduga tak bersalah."

Kemudian pasal di atas dijabarkan secara lebih detail tentang maksud dan tujuannya dalam penjelasan pasal yang ada dalam Undang-Undang Nomor 40 Tahun 1999 Tentang Pers, yang berbunyi: "Pers nasional dalam menyiarkan informasi, tidak menghakimi atau membuat kesimpulan kesalahan seseorang, terlebih lagi untuk kasus-kasus yang masih dalam proses peradilan, serta dapat mengakomodasikan kepentingan semua pihak yang terkait dalam pemberitaan tersebut."

Setelah menjelaskan tentang larangan bagi perusahaan pers untuk tidak menyiarkan informasi yang bersifat menghakimi atau menyimpulkan suatu perkara yang sedang

12. Wina Armada, Wajah Hukum Pidana Pers, Jakarta: Pustaka Kartini, 1989, hlm 53 . 
ditangani pengadilan, kemudian dimuatlah sanksi bagi perusahaan yang telah dianggap melanggar larangan tersebut, hal ini tercantum dalam Pasal 18 ayat (2) Undang-Undang Nomor 40 Tahun 1999 Tentang Pers, yang berbunyi: "Perusahaan pers yang melanggar ketentuan Pasal 5 ayat (1) dan ayat (2), serta Pasal 13 dipidana dengan pidana denda paling banyak Rp 500.000.000,00 (Lima ratus juta rupiah)."

Perusahaan pers yang telah dianggap melanggar ketetapan dalam pasal di atas, maka akan dikenai sanksi sebagaimana yang tertera dalam isi pasal di atas.

Tingginya tingkat pelanggaran hukum dan etika pers, berkaitan dengan realitas lemahnya peranan Dewan pers. Kelemahan Dewan Pers menyebabkan ia belum mampu berfungsi sebagai self regulatory body untuk mengawasi tingkah laku komunitas pers, serta menjadi wasit yang bijak. Pemberlakuan pasal fitnah, penghinaan dan pencemaran nama baik dalam Kitab Undang-Undang Hukum Pidana (KUHP), sering disorot tajam oleh para praktisi hukum dan praktisi jurnalistik karena dinilai banyak menghambat kebebasan berekspresi dan menyampaikan pendapat, khususnya bagi pers. $^{13}$

Tindak pidana sub judice rule termasuk dalam jenis kejahatan yang dilakukan secara non fisik. Sehingga dalam hal ini terdapat kesulitan untuk pembuktiannya. Dengan lahirnya Undang-Undang Nomor 14 Tahun 1985 Tentang Mahkamah Agung dan aturan dalam Undang-Undang Nomor 40 Tahun 1999 Tentang Pers, yang dapat memberikan manfaat dan berguna bagi masyarakat, dan dapat dijadikan sebagai bahan pertimbangan dalam menyiarkan atau memberitakan sebuah informasi bagi pers nasional, demi terciptanya suasana yang adil dan kondusif. Adapun di dalam Undang-Undang Nomor 14

13. Tjipta Lesmana, Pencemaran Nama Baik dan Kebebasan Pers antara Indonesia dan Amerika, Jakarta: Erwin Rika Press, 2005, hlm 150. 
Tahun 1985 dan di dalam Undang-Undang pers yang mengatur tentang penghormatan terhadap badan peradilan, proses peradilan dan melarang segala bentuk perbuatan yang dapat mengintervensinya.

Ketentuan yang ada dalam pasal Pasal 18 ayat (2) UndangUndang Nomor 40 Tahun 1999 merupakan ancaman pidana bagi setiap perusahaan pers yang menyiarkan sebuah berita atau informasi peristiwa dan opini yang tidak menghormati normanorma agama dan rasa kesusilaan masyarakat serta asas praduga tak bersalah. Kemudian perusahaan pers juga diancam pidana denda karena sikapnya

1. Tidak melayani hak jawab

2. Memuat iklan yang terlarang, misalnya merendahkan martabat seseorang.

\section{B. Sanksi Tindak Pidana Sub Judice Rule Menurut Hukum}

\section{Pidana Islam}

Dalam sejarah kehidupan Rosulullah, pernah terjadi suatu peristiwa yang berkenaan dengan penghinaan, yakni dalam peristiwa perang Tabuk. Dalam perang tersebut kaum munafiqin menghina para sahabat. Meskipun Rasulullah adalah orang yang paling penyayang terhadap semua makhluk dan serat dengan sifat pemaaf, namun dalam kejadian ini Rasulullah tidak terima terhadap penghinaan atau penistaan yang dilakukan kaum munafiqin terhadap para sahabatnya, Rasulullah tidak memaafkan mereka, meskipun sebagian dari mereka mengaku bahwa itu adalah sebuah candaan belaka, namun Rasulullah tetap tidak terima dan lantas membaca suatu ayat yang bunyinya sebagai berikut:

tidak usah kamu minta maaf, karena kamu kafir sesudah beriman. Jika kami mema'afkan segolongan dari kamu
} 
(lantaran mereka taubat), niscaya kami akan mengadzab golongan (yang lain) disebabkan mereka adalah orang-orang yang selalu berbuat dosa. (Q.S At-Taubah). ${ }^{14}$

Di ayat sebelumnya diceritakan bahwa ada beberapa orang dari kalangan orang-orang munafiq yang mengejek seraya menghina para sahabat, kemudian setelah Rasullullah mengetahui hal tersebut kemudian mereka meminta maaf, lantas kemudian Rasulullah membacakkan ayat di atas.

Dalam Islam kita mengenal istilah Ulil Amri (pemerintah) dan Qhodi (penegak hukum/badan peradilan). Ulil Amri adalah pemerintah yang menurut Islam adalah orang yang diberi mandat untuk memerintah suatu daerah (Negara), Ulil Amri juga bertugas untuk mengatur dan membuat kebijakan demi terciptanya keamanan bagi orang yang hidup di daerahnya, dalam hal ini Ulil Amri juga adalah orang yang berwenang untuk menciptakan suatu peraturan, sedangkan Qhodi sebagai badan yang berada di bawahnya adalah pihak yang diberi wewenang untuk memberi hukuman bagi pihak yang melanggar peraturan yang dibuat oleh Ulil Amri.

Agama Islam menganjurkan untuk mematuhi Ulil Amri/Umara' dan segala kebijakannya selama tidak bertentangan dengan syariat Allah, atau tidak mengandung unsur maksiat. Perintah untuk taat kepada Ulil Amri menempati urutan setelah perintah taat kepada Rosulullah SAW. ${ }^{15}$ Sehingga Islam melarang pemeluknya untuk tidak melakukan perbuatan yang sifatnya menentang terhadap Ulil Amri. Di sisi lain Qhodi juga termasuk bagian dari Ulil Amri atau bisa diistilahkan sebagai tangan kanan Ulil Amri, sehingga para ulama sepakat bahwa menentang Qhodi sama halnya menentang Ulil Amri, menghina Qhodi sama dengan menghina Ulil Amri. 
Maka kemudian timbullah larangan untuk tidak menghina Ulil Amri sekaligus Qhodi, di samping itu memang perbuatan menghina merupakan suatu perbuatan yang dilarang dalam ajaran agama Islam. Rasulullah pernah berkata:

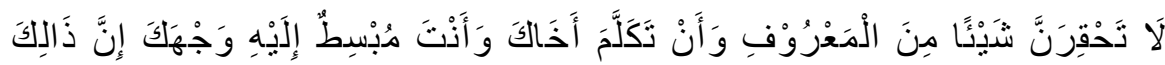

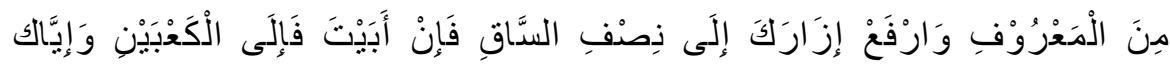

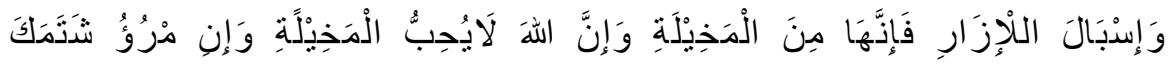

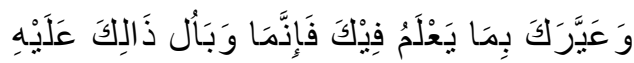

"Janganlah meremehkan kebaikan sedikitpun, walaupun engkau berbicara dengan saudaramu dengan wajah tersenyum kepadanya. Amalan tersebut adalah bagian dari kebajikan. Tinggikanlah sarungmu sampai pertengahan betis. Jika enggan, engkau bisa menurunkannya sampai mata kaki. Jauhilah memanjangkan kain sarung hingga melewati mata kaki. Penampilan yang seperti itu dalah tanda sombong, dan Allah tidak menyukai kesombongan. Jika ada seseorang yang menghinamu atau mempermalukanmu dengan sesuatu yang ia ketahui tentangmu, jangnlah engkau membalasnya dengan sesuatu yang engkau ketahui tentangnya. Biarlah akibat buruk iya sendiri yang menanggungnya."16

Dalam kandungan hadist di atas Rosulullah melarang kita untuk menghina sesama kita. Menghina seseorang yang sederajat saja dilarang, apa lagi penghinaan yang di tujukan kepada badan peradilan (Qhodi) sudah barang tentu larangan itu menjadi makin keras. Penghinaan terhadap badan peradilan di era sekarang ini, dapat dilakukan secara langsung dalam artian berhadap-hadapan kemudian menghinanya dengan kata yang bisa dianggap menghina, dan juga dapat dilakukan melalui tulisan di surat kabar, atau pemberitaan di televisi maupun internet. Model penghinaan secara tidak lansung dapat dilakukan dengan berbagai cara, diantaranya adalah dengan

16. Syihabuddin Ahmad, Irsyadussariy Lisyarhi Shohih Bukhori, Jilid 10, Mesir: Dar Al-Fikr, hlm 63 
penghinaan (Tahqir) tertulis yang secara jelas dan ditujukan kepada badan peradilan, bisa juga dengan menceritakan suatu kejadian yang dibugkus dengan opini-opini pribadi (Ghibah) di media sosial sehingga mengakibatkan banyak orang mempunyai anggapan buruk terhadap badan peradilan, atau dengan cara memberitakan adanya ketidakadilan yang dilakukan badan peradilan, namun pemberitaan tersebut tak mempunyai bukti nyata atas tuduhan dalam berita yang dimuat (al kadzbu fil khobar) di media sosial atau surat kabar. Beberapa tindakan di atas adalah sebagian perbuatan yang dapat mengandung unsur penghinaan terhadap badan peradilan (sub judice rule).

Istilah pemberitaan sub judice rule dalam Al-qur'an bisa diidentifikasi dari pengertian kata (الإ فأك) al-Ifk yang berarti keterbalikan (seperti gempa yang membalikkan negeri), tetapi yang dimaksud di sini ialah sebuah kebohongan besar. Dalam hal ini, Al-qur'an mengistilahkannya dengan kata usbah (عصبة). Kata usbah diambil dari kata'asaba (عصب) yang pada mulanya berarti mengikat dengan keras. Dari asal kata ini lahir kata muta'assib (متعصب) yakni fanatik. Kata ini dipahami dalam arti kelompok yang terjalin kuat oleh satu ide (pers), dalam hal ini menebarkan isu negatif ( $s u b$ judice rule). Adapun pelaku sub judice rule atau muta'assib itu sendiri biasanya memang sudah diniatkan dengan maksud tertentu. Kata (كبره) kibrahu terambil dari kata (كبر) kibr atau kubr yang digunakan dalam arti yang terbanyak dan tersebar. Yang dimaksud disini adalah yang paling banyak dalam menyebarkan berita. Allah berfirman dalam Q.S An-Nur ayat 11 yang berbunyi:

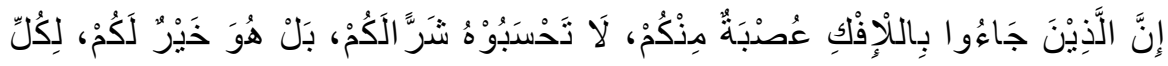

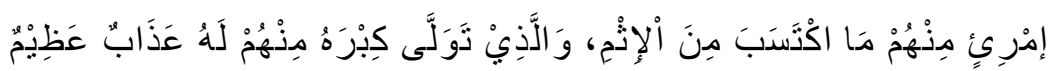

"Sesungguhnya orang orang yang membawa berita bohong itu adalah dari golongan kamu. Janganlah kamu mengira berita itu buruk bagi kamu bahkan itu baik bagi kamu. Setiap orang 
dari mereka akan mendapat balasan dari dosa yang diperbuatnya. Barang siapa di antara mereka yang mengambil bagian terbesar (dari dosa yang diperbuatnya), dia mendapat azab yang besar pula." 17

Dari kandungan ayat di atas dapat diketahui bahwa kabar bohong itu adalah salah satu ciri dari perbuatan orang munafiq dan kelak pelakunya akan mendapatkan azab yang teramat besar. Kita tau bahwa penghinaan terhadap badan peradilan dapat dilakukan dengan cara membuat kabar bohong yang merugikan badan peradilan dan mencoreng nama baik, martabat dan kehormatan badan peradilan. Jika penghinaan itu dilakukan dengan cara menyebarkan kabar bohong maka menurut ulama terdapat 2 hukum, hal ini jika kita merujuk pada sautu peristiwa yang menimpa Rosulullah, di mana pada saat itu Rosulullah sekaligus sebagai Ulil Amri bagi orang mu'min, telah terhina akibat kabar bohong yang disebarkan oleh orangorang munafiq tentang penyelewengan sayyidah aisyah. Ulama berbeda pendapat tentang sanksi bagi penyebar kabar bohong tersebut, apakah siksa duniawi berupa pencambukan delapan puluh kali diterapkan atas mereka yang terlibat atau tidak. Namun demikian meski mereka tidak terkena sanksi pencambukan, kecaman Ayat-Ayat ini serta pandangan negatif yang tertuju kepada mereka setelah turunnya Ayat-Ayat ini sungguh telah merupakan siksaan batin yang tidak kecil. ${ }^{18}$ Selain dengan kabar bohong penghinaan terhadap badan peradilan juga dapat dilakukan dengan cerita-cerita yang memojokkan atau hasut- menghasut di media sosial.

Menurut Al-Ghazali penghinaan sama saja dengan pencemaran nama baik, yakni perbuatan menghina (merendahkan) orang lain di depan manusia atau di depan

17. Lihat Al-Quran terjemahan, Mushaf Sidogiri. Pasuruan: Pustaka Sidogiri. hlm.351

18. M. Quraish Shihab. Tafsir Al-Misbah Pesan, Kesan dan Keserasian Al-Quran. vol. 8 Jakarta: Lentera Hati. 2002, 494 
umum. ${ }^{19}$ Sementara dalam kitab Tafsir Jalalain, Imam Jalaluddin membagi tiga model penghinaan, yaitu:

1. Sukhriyyah: yaitu meremehkan atau menganggap remeh orang lain karena sebab tertentu

2. Lamzu: adalah menjelek-jelekkan dengan cacian atau hinaan atau dengan kejelekan orang lain.

3. Tanabuz: adalah model cacian atau penghinaan dengan menyebut atau memanggil lawan bicara dengan sebutan yang jelek, dan sebutan yang paling buruk adalah memanggil wahai fasik atau wahai yahudi kepada orang Islam. ${ }^{20}$

Dalam hukum pidana Islam tindak pidana sub judice rule merupakan hal yang baru, dan belum ada dalam hukum pidana Islam yang mengatur secara spesifik baik dari segi teknis maupun jenis pelaksanaanya tentang tindak pidana sub judice rule.

Tindak pidana sub judice rule yang dilakukan dengan mencampuri atau mengintervensi sebuah proses peradilan dengan cara pemberitaan atau publikasi, yang diatur di dalam UndangUndang Nomor 40 Tahun 1999 Tentang Pers bisa diartikan seperti menyebarkan berita yang belum tentu pasti kebenarannya. Perbuatan tersebut adalah termasuk perbuatan yang dilarang dalam Islam. Untuk menentukan sanksi hukum bagi pelaku perbuatan sub judice rule, maka dapat menggunakan metode ijtihad yang berupa qiyas. Pada metode ini yang menjadi al-aslu (yang terdapat nas dan hukumnya) adalah memberitakan atau larangan menyebarkan berita sebelum dicek terlebih dahulu.

Sedangkan yang menjadi hukum asl adalah larangan menyebarkan suatu berita tanpa diteliti atau dikonfirmasi terlebih dahulu oleh pihak yang bersangkutan. Hal itu karena apabila berita

19. Abdul Hamid Al-Ghazali, Ihya al-Ulumuddin, Ciputat: Lentera Hati, 2003, hlm 379 .

20. Imam Jalaluddin, Tafsir Jalalain, Bandung: Sinar Baru Algesindo, 2010, 428. 
itu bohong maka dapat mencelakakan suatu masyarakat dan akan berakhir dengan penyesalan.

Menurut pandangan hukum pidana Islam ada beberapa poin yang harus dipenuhi dalam penyiaran atau pemberitaan di media massa, baik di televisi, surat kabar dan lain-lain. Poin-poin tersebut ialah sebagai berikut:

a. Tidak mengandung unsur kebohongan.

b. Tidak mendorong, menggugah, membangkitkan orang lain melakukan kemaksiatan ataupun kemungkaran.

c. Tidak menimbulkan fitnah

d. Tidak menyimpang dari syari'at.

e. Tidak menjawab orang lain malas/enggan melakukan hal-hal yang wajib secara syara'.

f. Tidak menyebarkan rahasia orang lain.

g. Tidak menyebabkan gunjingan. ${ }^{21}$

Maka dengan demikian menurut pandangan hukum Islam setiap penyiaran atau pemberitaan yang ada di media massa baik di televisi, surat kabar, internet dan lain-lain, yang isinya mengandung beberapa poin di atas hukum penyiarannya tidak boleh (Haram). ${ }^{22}$

Dalam sebuah kitab di sebutkan:

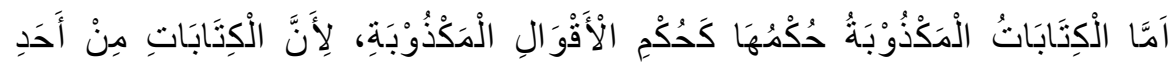

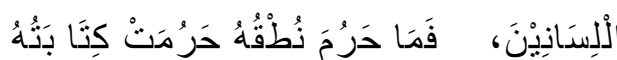

"Tulisan yang mengandung kebohongan hukumnya sama dengan dengan mengucapkan kebohongan itu sendiri. Karena tulisan adalah Salah satu bentuk dari ucapan, sehingga sesuatu yang haram untuk diucapkan maka haram pula untuk ditulis".

Tindak pidana sub judice rule dapat dikatakan jarimah jika telah memenuhi unsur-unsurnya, baik unsur jarimah yang

21. Tim Muroja'ah, Santri Salaf Menjawab, Jilid 3, Pasuruan: Pustaka Sidogiri, hlm 888

22. Ibid., hlm 889 
bersifat umum maupun khusus. Adapun unsur dalam perbuatan yang dianggap Jarimah adalah:

1. Pelaku adalah orang yang berakal dan sudah baligh, dalam hal ini lembaga pers tersebut tentunya dikepalai dan dijalankan oleh orang-orang professional yang pastinya berakal dan sudah dewasa (baligh).

2. Pelaku sub judice rule memberitakan sebuah peristiwa dan melakukan sebuah penggiringan opini pada masyarakat luas, yang dapat mengintervensi proses peradilan.

3. Pelaku tindak pidana sub judice rule dalam hal ini berniat untuk mengambil keuntungan pribadi atau misi tertentu, tanpa mengindahkan asas praduga tak bersalah (Husnudzon) kepada objek pemberitaan, yang dalam hal ini belum tentu melakukan kesalahan yang dituduhkan padanya. ${ }^{23}$

Sanksi untuk kejahatan tindak pidana yang diberlakukan pada jarimah bukan semata-mata untuk bukti pembalasan dendam, namun lebih kepada bimbingan dan pengayoman. Ini seperti pendapat Imam Al-Mawardi, bahwa takzir adalah hukuman bagi tindak pidana yang belum ditentukan hukumannya oleh syara' yang bersifat mendidik. Maksud dari mendidik di sini adalah untuk mencegah terjadinya maksiat pada masa yang akan datang. Pengayoman sekaligus kepada masyarakat dan kepada terpidana sendiri agar menjadi masyarakat dan kepada terpidana khususnya agar menjadi masyarakat yang baik. Demikianlah konsepsi baru fungsi pemidanaan yang bukan lagi sebagai penjeraan belaka, namun juga sebagai upaya rehabilitasi, konsepsi itu di Indonesia disebut permasyarakatan. ${ }^{24}$

Sanksi hukuman tindak kejahatan sub judice rule dalam Pasal 18 ayat (2) Undang-Undang Nomor 40 Tahun 1999 
tentang pers yang berbunyi: "Perusahaan pers yang melanggar ketentuan Pasal 5 ayat (1) dan ayat (2), serta Pasal 13 dipidana dengan pidana denda paling banyak Rp 500.000.000,00 (Lima ratus juta rupiah)". Penjelasan Pasal tersebut menyatakan bahwa dalam hal pelanggaran pidana yang dilakukan oleh perusahaan pers, maka perusahaan tersebut diwakili oleh penangung jawab yang meliputi bidang usaha dan redaksi.

Redaksi di atas telah sesuai dengan hukum pidana Islam, yakni menukil dari pendapat 4 Imam Madzhab: Imam Abu Hanifah membolehkan sanksi takzir dengan hukuman mati apabila perbuatan itu dilakukan berulang-ulang dan dapat membawa kemaslahatan bagi masyarakat. ${ }^{25}$ Contohnya menyebarkan berita bohong yang membawa dampak buruk bagi masyarakat banyak dan menghina Nabi beberapa kali seperti yang dilakukan oleh kafir dzimmi. Sedangkan Imam Malik, Imam Syafi'i serta Imam Ahmad bin Hanbal berpendapat bahwa diperbolehkan hukuman takzir dengan cara mengambil harta seseorang apabila membawa maslahat. Takzir pengambilan harta tersebut dibagi menjadi tiga bagian, yaitu: menghancurkannya, mengubahnya dan memilikinya, dan point terakhir yakni, (memilikinya) yang berarti memberikan denda terhadapnya. Sebagaimana khalifah Umar bin Khattab pernah memberikan denda kepada seorang yang mencuri kambing sebelum ke tempat penggembala. Sehingga hukuman yang berupa denda telah sesuai dengan sanksi jarimah takzir. Dengan demikian kejahatan criminal contempt dalam bentuk sub judice rule telah memenuhi unsur-unsur yang ada dalam jarimah takzir.

\section{Kesimpulan}

25. M. Nurul Irfan, Hukum Pidana Islam, Jakarta: Amzah, 2013, hlm 96. 
1. Tindak sub judice rule merupakan suatu bentuk tindakan contempt of court, hanya saja sarananya adalah dengan menggunakan pers. Bentuk penghinaan yang terkandung dalam perbuatan sub judice rule ialah keikutsertaan pers dalam kasus-kasus yang masih dalam penanganan badan peradilan, berupa pemberitaan yang dibuat berdasarkan asumsi dan menghakimi terhadap hal-hal yang tidak masuk pada ranah wewenang pers itu sendiri. Tindakan ini dianggap menyalahi aturan atau undang-undang dan akibat dari tindakan $s u b$ judice rule ini dapat mengintervensi atau mempengaruhi keputusan badan peradilan dalam menyelesaikan suatu kasus, dan juga dapat memicu aggapan miring masyarakat terhadap nilai-nilai keadilan yang diemban oleh badan peradilan sehingga nama baik, martabat, dan kehormatan badan peradilan dapat tercoreng.

Setelah tindakan sub judice rule dikaji dengan menggunakan kacamata undang undang pers, maka sanksi bagi pihak pers yang terbukti melakukan tindakan sub judice rule ialah denda sebesar Rp 500.000.000.00. dan denda ini dibebankan kepada penanggungjawab dari perusahaan pers tersebut. Terdapat dua ketegori dalam sanksi ini, jika dalam isi berita tidak mencantumkan nama penulis maka yang bertanggungjawab adalah penanggungjawab perusahaan, jika mencantumkan nama maka dalam kasus ini undang undang pers tidak bisa digunakan untuk sarana hukum, akan tetapi harus melewati jalur pasal-pasal dalam KUHP, meskipun selama ini dalam penerapannya antara para penegak hukum selalu saja berbeda sudut pandang dalam menyikapi pelanggaran pers.

2. Tindak pidana sub judice rule jika ditarik pada pengertian yang ada dalam konsep Islam maka lebih mengarah pada dua hal. Satu jika memang isi dari berita itu adalah aib seseorang atau lembaga yang pada kenyataanya memang demikian adanya maka berita itu dianggab ghibah. Dua apabila isi dari pemberitaan itu merupakan sebuah persangkaan yang tak dapat dibuktian dengan bukti-bukti yang bisa dipertanggung jawabkan maka itu dianggap sebagai 
sebuah kebohongan, hal ini jika mengacu pada kandungan hadist tentang ghibah dan juga cerita bohong dalam Q.S An-Nur ayat 11 yang telah terjabarkan di pembahasan. Sanksi bagi tindakan sub judice rule dalam al-qur'an dan hadist tak ditemukan, sehingga hukuman untuk tindakan sub judice rule masuk pada kategori hukuman takzir, yang dalam bentuk dan pelaksanaannya dipasrahkan kepada Qhodi. Qhodi adalah pihak yang mempunyai wewenang dalam memberi hukuman bagi pelaku sub judice rule tentunya dengan meninjau berbagai aspek.

\section{Daftar Pustaka}

Abdul Hamid Al-Ghazali, 2003, Ihya al-Ulumuddin, Ciputat:

LenteraHati.

Al-Qur'an terjemahan Mushaf Sidogiri Pasuruan: Pustaka Sidogiri cetakan ke I

Armada Sukardi Wina, 1990, Keutamaan di Balik Kontroversi Undang-Undang Pers, Jakarta: Pustaka Kartini.

Baudrillard Jean, 2001 Galaksi Simulacra. LKiS.

Hamzah Andi, 1989, Delik-Delik TerhadapPenyelenggaraanPeradilan (Contempt Of Court) Jakarta: Sinar Grafika,

Hasan At-Tibasi, T-Tahun, Al-Fisbuk Wa Ma Yata'allaqu Bihi, Maktabah Tibasiyah,

https://m.merdeka.com/pendidikan-contoh-kasus-pelanggarankebebasan-pers-di-indonesia

Ibrahim Johnny, 2010 Teori \& Metodologi Penetitian Hukum Normatif. Malang: Bayumedia Publishing.

Imam Ibrohim, 1971, Tuhfatu Al-Murid, Libanon: Dar Al- Kotob,

Imam Jalaluddin, 2010, Tafsir Jalalain, Bandung: Sinar Baru Algesindo. 
Kusumaningrat Hikmah dan Kusumaningrat Purnama, 2012 Teori dan Praktik, Bandung: Cetakan Kelima, PT. Remaja Rosdakarya

Lesmana Tjipta, 2005, Pencemaran Nama Baik dan Kebebasan Pers antara Indonesia dan Amerika, Jakarta: Erwin Rika Press.

M. Nurul Irfan, 2013, Hukum Pidana Islam, Jakarta: Amzah.

Marpaung Leden, 2010 Tindak Pidana Terhadap Kehormatan. Sinar Grafika. Cetakan I

Rahmat Hakim, 2000, Hukum Pidana Islam, Bandung: Pustaka Setia.

Seno Adji Oemar, 1986 Peradilan Bebas \& Contempt of Court. Jakarta: Erlangga.

Seno Adji Oemar, 1986, Contempt of Court suatu pemikiran, Jakarta:Erlangga.

Shihab M. Quraish 2002. Tafsir Al-Misbah Pesan, Kesan dan Keserasian Al-Quran. vol. 8 Jakarta: Lentera Hati

Syihabuddin Ahmad, Irsyadussariy Lisyarhi Shohih Bukhori, Jilid 10, Mesir: Dar Al-Fikr.

Tim Muroja'ah, Santri Salaf Menjawab, Jilid 3, Pasuruan: Pustaka Sidogiri

Undang-Undang No. 40 Tahun 1999 Tentang Pers

Undang-Undang Nomor 8 Tahun 1981 Tentang KUHAP

Waluyo Bambang, 2000, Pidana dan Pemidanaan, Jakarta: Sinar Grafika. 